\title{
Relative speed and temperature effect investigation of the of the drying agent on the moisture content of cotton
}

\author{
Khayridin Rakhmonov ${ }^{*}$, Sirojiddin Fayziev, Khakimboy Rakhimov, and Dilfuza Kazakova \\ Bukhara Engineering-Technological Institute, Bukhara, Uzbekistan
}

\begin{abstract}
In this article, the influence of the relative air velocity and temperature on the moisture transfer rate for raw cotton is studied. At relative air velocities varying from $0.05-0.6 \mathrm{~m} / \mathrm{s}$ using a laboratory setup and different temperatures of the drying agent and humidity of raw cotton, the dependences characterizing the process of moisture sampling and desorption (drying) of raw cotton, as well as the diffusion process occurring inside the sample, are obtained.
\end{abstract}

\section{Introduction}

It is known that, depending on the state of moisture in the material and the possibility of its removal, there are free and hygroscopic, as well as excess and equilibrium moisture. Free moisture is determined by the well-known formula $[1,3]$.

$$
U_{c b}=U-U_{h}
$$

Here, $U_{h}$ is maximum hygroscopic moisture content of the material

$U$ is total moisture content of the material

\footnotetext{
* Corresponding author: raxmon@mail.ru
} 


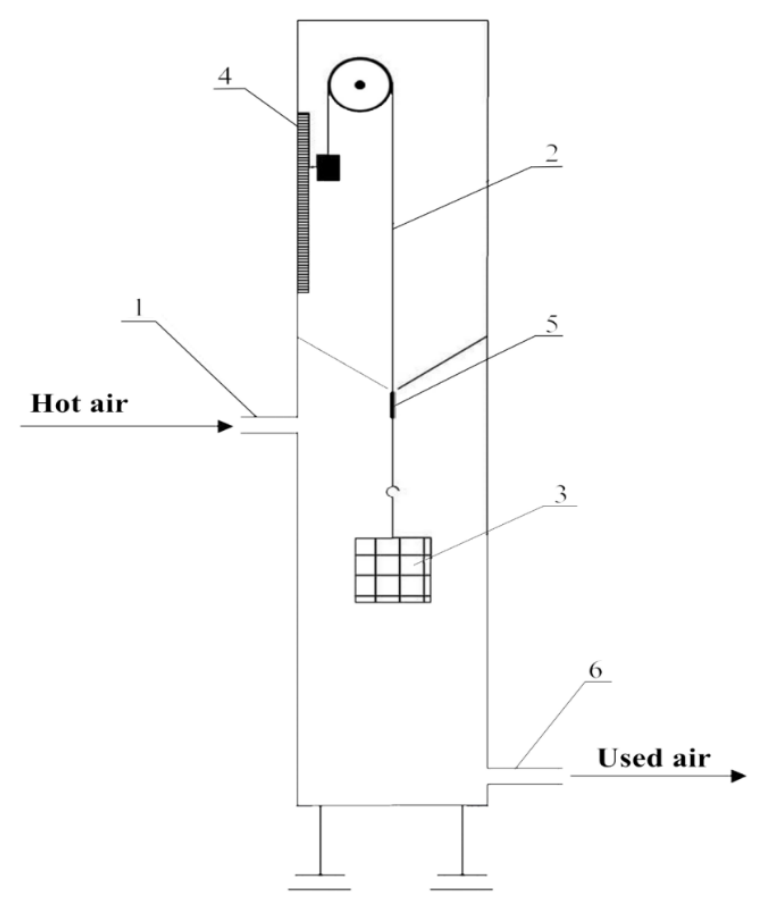

Fig. 1. Laboratory installation for the determination of moisture sampling: 1 is hot air supply pipe, 2 is samplle support case, 3 is wet cotton basket, 4 is counterweight, 5 is needle valve, 6 is waste moisture.

Wet material can release moisture by evaporating it under certain conditions into the environment, but it can also absorb moisture from the environment. When drying raw cotton, excess moisture is mainly absorbed, consisting of free and part of the hygroscopic moisture. The study shows that excess moisture leads to a loss of fiber quality and reduced machine performance, and low humidity can lead to fiber breakage and difficult operation. The rate of moisture transfer from raw cotton depends on the speed of air. It is known that moisture, like most other vapor and liquid mixtures, is transferred from an area with high pressure (or concentration) to an area with a lower vapor pressure potential $[2,4]$.

The transfer rate depends on the gradient and flow resistance between the two regions. This gradient can be enhanced by increasing the temperature and removing stagnant air from the layer. In most cases, in cotton gins, when drying raw cotton, an increased speed is used to increase the moisture intake. But it always does not give a positive result due to the high density of wet cotton [5-7].

\section{Methods}

The purpose of this study was to determine the effect of the relative speed of the drying agent and the density of raw cotton on the rate of moisture extraction and desorption (drying)at a certain temperature. The volume flow rate of hot air passing over the image through it and around it varied $50-120 \mathrm{~cm}^{3} / \mathrm{s}^{-1}$. Depending on the sample holder used, the relative air velocity through the tube varied from $0.05-0.6 \mathrm{~m} / \mathrm{s}$. Figure 1 shows the installation for determining the effect of density on the moisture sampling process.

The unit consists of 2 chambers: upper and lower, which has an air intake pipe 1, a wire to support the sample 2, a basket for wet raw cotton 3 and an outlet pipe 6 for exhaust air, a 
counterweight 4 and a needle valve. Hot air enters the upper part of the chamber and passes around the sample before being released into the atmosphere.

The flow rate was controlled by needle valves 5 and measured with an anemometer AM-1 with an accuracy of $0.03 \mathrm{~cm}^{3} / \mathrm{s}$. The air temperature in the study was $40^{\circ} \mathrm{C}, 50^{\circ} \mathrm{C}$, $60^{\circ} \mathrm{C}$. When selecting and testing laboratory samples, we followed the methods provided for by the current requirements of O'ZDST 642-2013 and O'ZDST 644-2006, as well as using the-HVI system. Samples of different varieties were selected for the study. To control the air temperature, SIM-12 H temperature sensors were used with an accuracy of $0.2{ }^{\circ} \mathrm{C}$, located higher from the sample [9-11].

The air entered the upper part of the chamber and passed around the sample before entering the atmosphere. Preliminary a priori surveys of specialists and experiments have shown that the density of raw cotton significantly impacts the drying rate and its humidity. Therefore, a sample mass in the range of 50 to $100 \mathrm{~g}$ was selected for the experiment, providing a density range of 0.5 to $2.8 \mathrm{~g} \mathrm{~cm}^{-3}$. The samples were placed in a basket chamber and kept until the test temperature was affected to a dry state[12-14].

During the required time, they were exposed to a temperature at different air speeds. The moisture content of raw cotton will approach equilibrium due to the diffusion process. The equation of the diffusion process can be written through a three-dimensional equation $[10,15]$.

$$
\frac{\partial c}{d \theta}=k \frac{\partial^{2} c}{\partial x^{2}}+\frac{\partial^{2} c}{\partial y^{2}} \frac{\partial^{2} c}{\partial z^{2}}
$$

Here,

$\mathrm{c}$ is water vapor concentration

$\theta$ is time

$\mathrm{k}$ is diffusion coefficient

$\mathrm{x}, \mathrm{y}$, and $\mathrm{z}$ are Deckard coordinates.

These equations can be simplified by using Newman [3] equation for gases.

$$
\frac{M-M_{\mathrm{E}}}{M_{0}-M_{\mathrm{E}}}=\beta\left\lfloor\frac{1}{\alpha} e^{-\alpha D \theta}+\frac{1}{\gamma} e^{-\gamma D \theta}+\frac{1}{-\eta} e^{-\eta D \theta}\right\rfloor
$$

Where from

$\mathrm{M}$ is moisture content of raw cotton

$\mathrm{M}_{0}$ is initial moisture content of raw cotton

$\mathrm{M}_{\mathrm{E}}$ is intermediate moisture content of raw cotton (at equilibrium)

$\beta$ is $6 / \pi ; 8 / \pi$ for spherical and 4 for flat and cylindrical (for calculations $0.7346,0.8687$ and 4.564 were accepted)

$\alpha$ is 1 and 5, 78, 31 for spherical and flat and cylindrical

$\mathrm{D}$ is the diffusion coefficient, $\mathrm{min}^{-1}$

$\gamma$ is the coefficient that takes into account the air density (for calculations 4.9 and 30.4 are accepted)

$\eta=9.25$ and 74,89 for flat and cylindrical

Based on the results of the experiments, we get the following dependencies.

\section{Results and Discussion}

Based on the results of the experiments, I will use the program Matlab for a flat and spherical environment. The dependences of the characterized process of moisture sampling are obtained: 


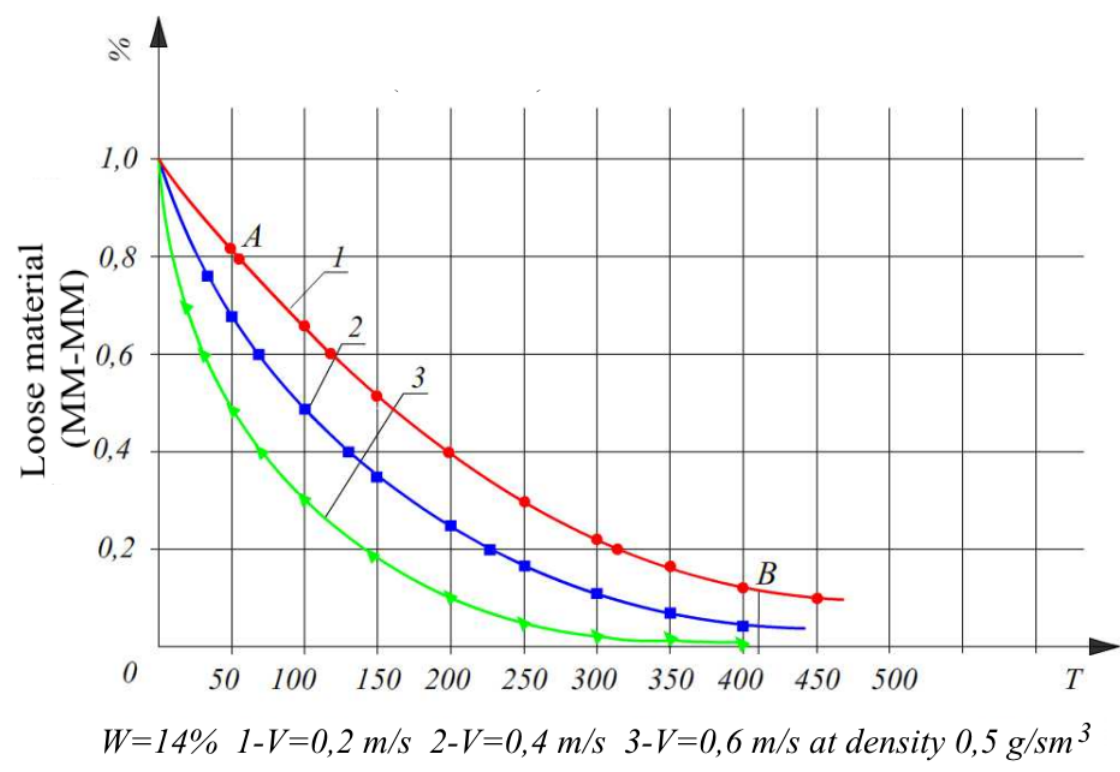

Fig. 3 Dependence of the moisture intake of raw cotton on the speed of the drying agent at a temperature of $50^{\circ} \mathrm{C}$

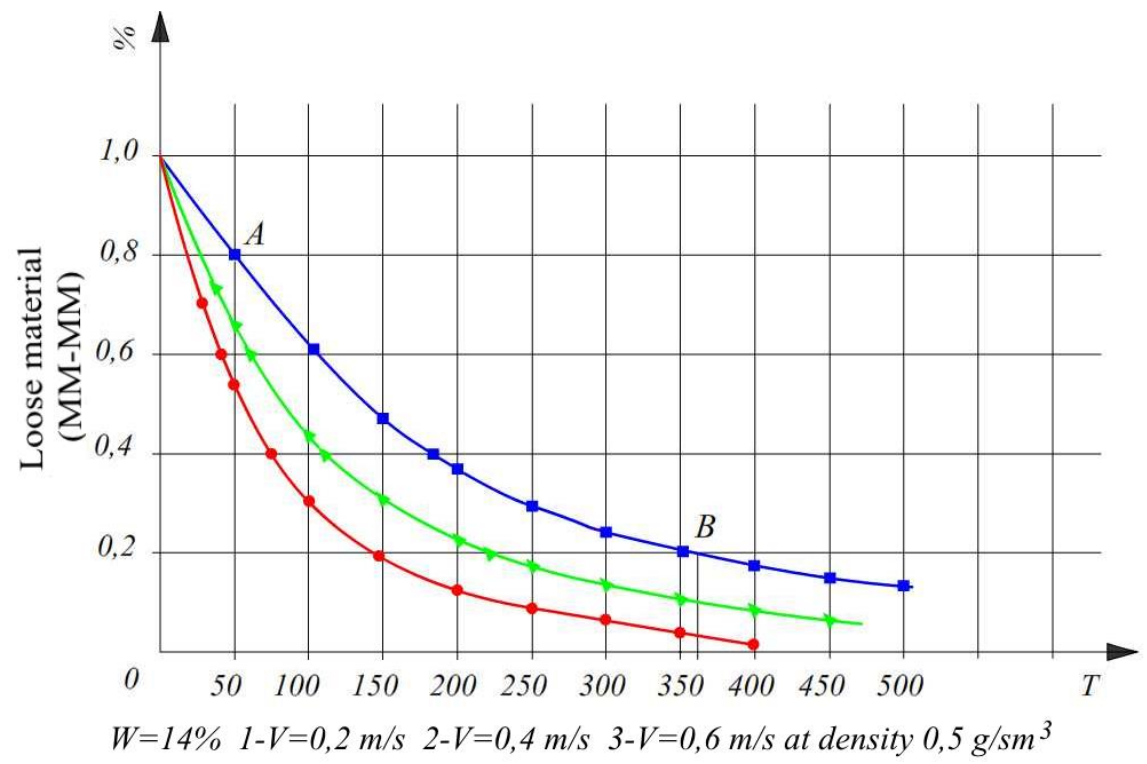

Fig. 4. Dependence of the moisture intake of raw cotton on the speed of the drying agent at a temperature of $60^{\circ} \mathrm{C}$ 


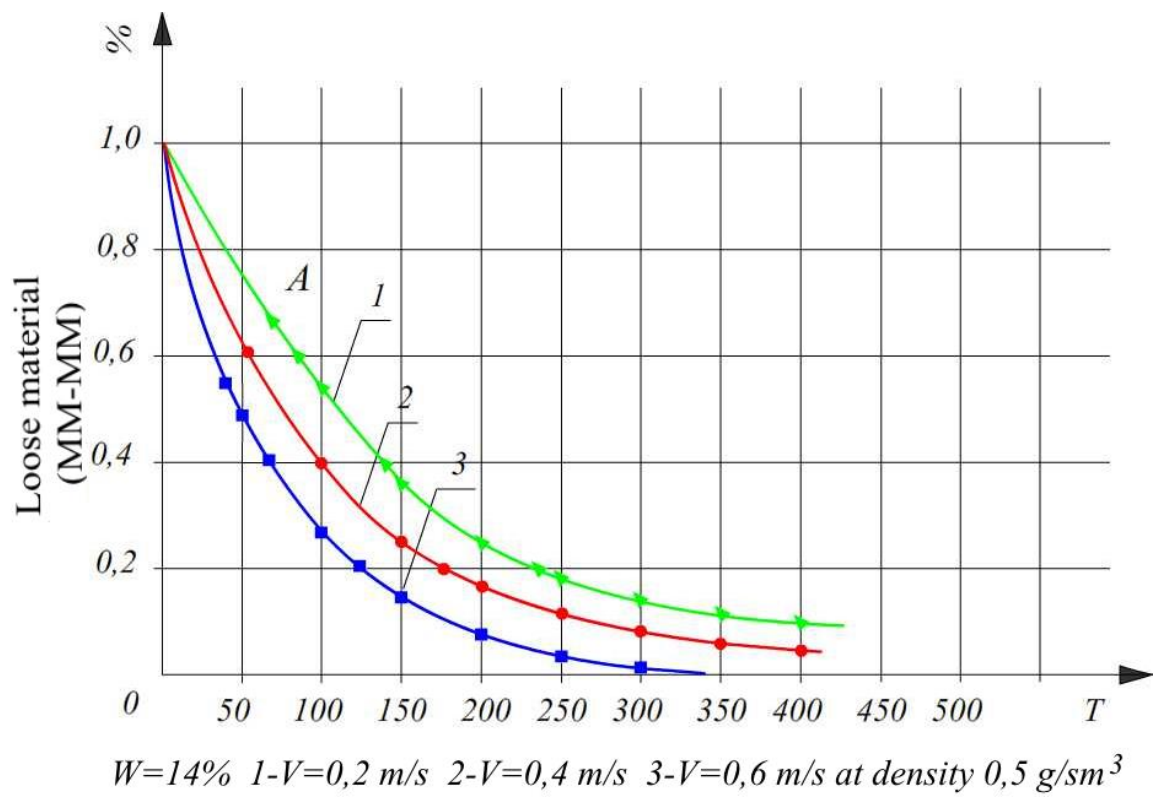

Fig. 5 Dependence of the moisture intake of raw cotton on the speed of the drying agent at a temperature of $70^{\circ} \mathrm{S}$

The analysis of the obtained dependences in figure 2, 3, 4 shows that the relative rate of moisture transfer for raw cotton during the hydration phase may have a negligible effect during the drying phase. The graph shows that the relative velocity has some influence on the rate of moisture extraction $[16,17]$

From the curve, it can be seen that first, the process of moisture extraction goes in the form of a straight line In, and then passes into the curve, i.e. at the beginning of the drying process does not depend on humidity and is a constant value. The first critical point A indicates the end of the period of constant speed occurs after 75 seconds at a humidity of $12.8 \%$ of the beginning of the period of falling speed. Hence, it can be seen from the graph that during the period of the falling velocity, there is a second point, the so-called singular $\mathrm{B}$, showing the zone of external and internal diffusion [18 - 20].

During the period of constant speed, when at $50{ }^{\circ} \mathrm{C}$, the moisture content decreases from $14 \%$ to

by $\mathrm{V}=0.2 \mathrm{~m} / \mathrm{s} \mathrm{W}=13.2 \%$

by $\mathrm{V}=0.4 \mathrm{~m} / \mathrm{s} \mathrm{W}=12.8 \%$

by $\mathrm{V}=0.6 \mathrm{~m} / \mathrm{s} \mathrm{W}=11.9 \%$

If the temperature of the drying agent is $60{ }^{\circ} \mathrm{C}$, the moisture content of the material is reduced from $14 \%$ to

by $\mathrm{V}=0.2 \mathrm{~m} / \mathrm{s} \mathrm{W}=12.8 \%$

by $\mathrm{V}=0.4 \mathrm{~m} / \mathrm{s} \mathrm{W}=12.1 \%$

by $\mathrm{V}=0.6 \mathrm{~m} / \mathrm{s} \mathrm{W}=11.3 \%$

If the temperature of the drying agent is $70{ }^{\circ} \mathrm{C}$, the moisture content of the material is reduced from $14 \%$ to

by $\mathrm{V}=0.2 \mathrm{~m} / \mathrm{s} \mathrm{W}=12.3 \%$

by $\mathrm{V}=0.4 \mathrm{~m} / \mathrm{s} \mathrm{W}=11.8 \%$

by $\mathrm{V}=0.6 \mathrm{~m} / \mathrm{s} \mathrm{W}=10.6 \%$ 


\section{Conclusions}

Thus, the results were obtained at the relative speed of the drying agent, varying from 0.2 to $0.6 \mathrm{~m} / \mathrm{s}$ for the agent. As expected, the temperature had a pronounced effect on the moisture content of raw cotton at different temperatures of the drying agent. An increase in the relative speed of the drying agent increased the rate of moisture transfer. However, cotton seeds and fibers exposed to hot air showed no visible changes in structural properties. Thus, the relative speed and temperature of the drying agent has a significant impact on the moisture content of cotton and the quality of the fiber, that is, its effect on the cleaning and ginning process, which should be further studied.

\section{References}

1. Rakhmonov Kh.K. Preliminary processing of light industrial raw materials, Publishing house polygraph, Bukhara (2018)

2. Newman A.B. The drying of porous solids, Diffusion calculations, Chem. Eng. 27, pp. 310-333, Trans. Am. Inst. (1932)

3. Teshaev M.K., Safarov I.I., Kuldashov, N.U., Ishmamatov, M.R., Ruziev, T.R. On the Distribution of Free Waves on the Surface of a Viscoelastic Cylindrical Cavity, Journal of Vibrational Engineering and Technologies, 8(4), pp. 579-585, (2019)

4. Rakhmonov Kh.K., Fayziyev S.Kh. Improvement of equipment and technology of drying of the cotton mass and its technological assessment on the basis of its thermal properties, International journal of advanced research in science, engineering and technology. 6 (5), pp. 9496-9500, May 2019

5. Fayziyev S.Kh., Rakhimov Kh.K. Creation of a New Design of a System for Feeding raw Cotton to a Cylinder, International Journal of Recent Technology and Engineering (IJRTE), 8(4), pp. 12753-12759, November (2019).

6. Rakhmonov Kh.K., Fayziyev S.Kh., Study of Effect of Speed and Temperature of the Drying Agent in the Feeder-Loosened of New Design on the Quality of Fiber, International Journal of Emerging Trends in Engineering Research, (8). № 10, pp. 7008-7013, October (2020)

7. Rakhmonov Kh.K., Fayziyev S.Kh., Qodirova D.Kh.: Device for feeding and drying raw cotton, Patentfor useful model. FAP 01544.

8. Safarov I.I., Teshaev M.Kh., Boltayev Z.I. Propagation of linear waves in multilayered structural-Inhomogeneous cylindrical shells, Journal of Critical Reviews, 7(12), pp. 893-904, (2020) http://jcreview.com/

9. Teshaev M.K., Safarov I.I., Kuldashov N.U., Ishmamatov, M.R., Ruziev, T.R. On the Distribution of Free Waves on the Surface of a Viscoelastic Cylindrical Cavity, Journal of Vibrational Engineering and Technologies, 8(4), pp. 579-585 (2019) https://link.springer.com/ article/ 10.1007/s42417-019-00160-x

10. Safarov I., Teshaev M., Toshmatov E., Boltaev Z., Homidov F. Torsional vibrations of a cylindrical shell in a linear viscoelastic medium, IOP Conference Series: Materials Science and Engineering, 883(1), pp. 012190 (2020)

11. Fayziev S., Rakhmonov Kh., Rakhimov Kh., Ibodullaev O., Mirzoyeva S. Theoretical, practical and experimental research on the creation of an energy-saving universal screw in a new design of the transfer line of the drying drum of raw cotton, THE SCIENTIFIC JOURNAL "THE ARCHIVIST» Tom 7 № 1 (55). pp.42-49

12. Rakhmonov Kh., Fayziev S., Rakhimov Kh., Toyirova G., Mirzoyeva S. Screw mixerfeeder for drying drum, SCIENTIFIC ELECTRONIC JOURNAL " MATRIX OF SCIENTIFIC KNOWLEDGE, №. 1-2/2021, pp. 68-73, January (2021) 
13. Fayziev S. Theoretical studies of the process of drying raw cotton in drying drums. Academy. Scientific and Methodological Journal 4(43), pp. 15-18, April (2019)

14. Fayziev S Kh., Rakhmonov Kh.K., Rakhimov Kh.K., Mukhtarova Z.N. Improving the transfer network of raw cotton to the drying drum, International Journal of Advanced Research in Science, Engineering and Technology 7(11), pp. 15578-15583, November (2020)

15. Mirsaidov M.M., Safarov I.I., Teshaev M.K., BoltayevZ.I. Dynamics of structural Inhomogeneous coaxial-multi-layered systems cylinder-shells, Journal of Physics, Conference Series, 1706(1), 012033 (2020) doi:10.1088/1742-6596/1706/1/012033

16. Rajabov O. I. Abrorov A. S. Mirzaqulova N. I. Zaripov G.B. Ziyodullaev Kh.S., An experimental study of the location of the grid bars cells installed under spiked cylinders in a cotton cleaner from small waste, IOP Conference Series, Materials Science and Engineering, 734(1) p. 012073. (2020)

17. Rajabov O.I. The influence of the mode of movement of the pieces cotton when interacting with a cotton grid, International Journal of Advanced Research in Science, Engineering and Technology, 6(3), pp. 8455-8381, India (2019)

18. Abrorov A., Kuvoncheva M., Rajabov O., Mukhammadov M., Jumaev, S. Method of thermal treatment of saw disk teeth of fiber-processing machines by laser quenching. IOP Conference Series, Materials Science and Engineering, 862, p. 032034. (2020)

19. Urinov N., Saidova M., Abrorov A., Kalandarov N. Technology of ionic-plasmic nitriding of teeths of disc saw of the knot of saw cylinder, IOP Conference Series, Materials Science and Engineering, 734(1), (2020).

20. Rakhmonov Kh.K. The analysis of dynamics of the machine unit with the mechanism of the screw conveyor of the distributor of raw cotton, Science and practice: a new level of integration in the modern world, Conference Proceedings. B\&M Publishing, pp.45-49, USA, San Francisco, California, (2018) 